\title{
Intein-mediated recombinant expression of monomeric B22Asp desB30 insulin
}

\author{
Minmin Zhang ${ }^{1}$, Yunlong Zhang ${ }^{1}$, Bingnan Wu' ${ }^{1}$ Yanhao Peng ${ }^{1}$, Altaf Ahmed Simair ${ }^{1}$, Geoffery W. Siegel², \\ Changrui Lü ${ }^{* *}$ and Ting Chen ${ }^{*}$
}

\begin{abstract}
Background: Insulin controls hyperglycemia caused by diabetes, and virtually all treatments require exogenous insulin. However, the product's extensive post-translational modifications have hindered the manufacture of recombinant insulin.

Result: Here we report a novel production method for a monomeric B22Asp desB30 insulin analog (B22D desB30 insulin). Its precursor, DPIP, is fused to an N-terminal chitin-binding domain and intein self-cleavage tag. The fusion protein is expressed and purified from E. coli and immobilized on chitin resins. DPIP is then released using an optimized pH shift and converted to mature insulin via trypsin digest. The resulting product appears monomeric, > $90 \%$ pure and devoid of any exogenous enzyme.
\end{abstract}

Conclusion: Thus, biologically active insulin analog can be efficiently produced in bacteria and potentially applicable in the treatment of human diabetes.

Keywords: Intein, B22D desB30 insulin, Self-cleavage, Optimization

\section{Background}

Diabetes mellitus in human causes elevated blood sugar levels for a prolonged period of time [1]. If untreated, the disease may progress into many life-threatening complications, like kidney disease, blindness, and amputations [2]. Virtually all patients require regular intake of exogenous insulin, which lowers their blood glucose concentration. Studies suggest that the disease affects hundreds of millions of people, with an annual cost rapidly approaching one trillion dollars [3].

Since 1977, production of animal insulin has gradually exited the market as recombinant human insulin emerged [4]. However, since the human insulin monomers readily aggregate into multimers, the recombinant wild type human insulin displays a delay in treating hyperglycemia [5]. Therefore, its monomeric analogs, termed fast-acting insulins, are developed and clinically proven to match human endogenously produced insulin $[4,6]$. However, both the manufacturing process and

\footnotetext{
* Correspondence: crlu@dhu.edu.cn; chenting@dhu.edu.cn

${ }^{1}$ Key Laboratory of Science and Technology of Eco-Textiles, Ministry of Education, College of Chemistry, Chemical Engineering and Biotechnology, Donghua University, 2999 North Ren Min Rd, Shanghai 201620, China Full list of author information is available at the end of the article
}

composition of these patented insulin analogs are closely guarded commercial secrets. Due to the increasing diabetic population and rapidly rising cost, the market urgently requires the development of low-cost, fast-acting insulin analogs, especially in the underdeveloped and developing nations.

Here we report recombinant production of a fastacting insulin analog, termed B22D desB30, matured from a single-chain precursor. In vivo assays have shown that analogs of B22D desB30 stays monomeric and exhibits $30-40 \%$ activity, compared to the human endogenous counterpart [7-9]. However, structural changes that prevented multimerization also possibly destabilized its overall folding and hence made production difficult [10]. Therefore, we opted to recombinantly express and purify the $\mathrm{B} 22 \mathrm{D}$ desB30 precursor by protein splicing, which yielded single chain insulin precursor (B22D-PIP or DPIP).

Protein splicing involves the precise excision of an intein from a primary translation product concomitant with the ligation of the exteins via a peptide bond [11]. This autocatalytic process occurs post-translationally, without other enzymes or any cofactors [12, 13]. Several biotechnological applications explore the splicing 
properties of inteins, including protein purification, peptide cyclization and protein labeling [14-16]. Among them, the intein mediated purification with an affinity chitin-binding tag (two Intein or IMPACT-TWIN by New England Biolabs) provides a low-cost, convenient system, in which the target protein is immobilized by a single-step affinity enrichment and collected by intein self-cleavage that removes the affinity tag $[17,18]$. Using this process, we obtained the native protein without any affinity tag or exogenous proteases. Subsequent tryptic digestion produced pure, monomeric B22D des30 insulin analog.

\section{Results and discussion}

\section{CBD-intein1-DPIP fusion protein expresses in the inclusion body}

The recombinant $\mathrm{B} 22 \mathrm{D}$ desB30 produced in this study is converted from a precursor (DPIP) fused to a CBDintein tag. Fig. 1a shows the recombinant expression scheme of B22D desB30 insulin analog. The construct CBD-Intein-DPIP was confirmed by sequencing and all expression was carried out at similar conditions.

The recombinant fusion protein is consistently expressed at a high level (Fig. 1b, lane 2). Most likely the target protein collects in the inclusion body and is insoluble. The fusion protein expresses well in the inclusion bodies and was insoluble, consistent with precious studies [20,21]. After collecting the pellet after cell lysis, the fraction that redissolved after urea treatment is enriched with the $36 \mathrm{kDa}$ target protein (Fig. 1b, lane 4). Solubilizing the inclusion bodies with urea allows the ready purification of the fusion protein to near homogeneity. Subsequent affinity chromatography traps nearly all renatured fusion protein on the chitin matrix. All renatured protein binds to the column after dialysis, which suggests that the re-naturation process correctly restored native protein folding (Fig. 1b, lane 5). The CBD-intein tag also allows a $\mathrm{pH}$-induced auto-cleavage at the $\mathrm{N}$ terminus of the insulin precursor, releasing the peptide without exogenous protease or tags.

Since intein cleavage is sensitive to both temperature and $\mathrm{pH}$, we aim to fine-tune the reaction condition to maximize purification efficiency. This allows the most efficient release of the target DPIP with simple temperature and $\mathrm{pH}$ shift. By carrying out the cleavage reaction at three different temperatures $\left(10^{\circ} \mathrm{C}, 25^{\circ} \mathrm{C}\right.$ and $\left.30^{\circ} \mathrm{C}\right)$ and eight $\mathrm{pH}$ conditions $(4.5$ to 8.0, 0.5 interval), our study shows that the intein selfcleave reaction is strictly temperature- and $\mathrm{pH}$-dependent.

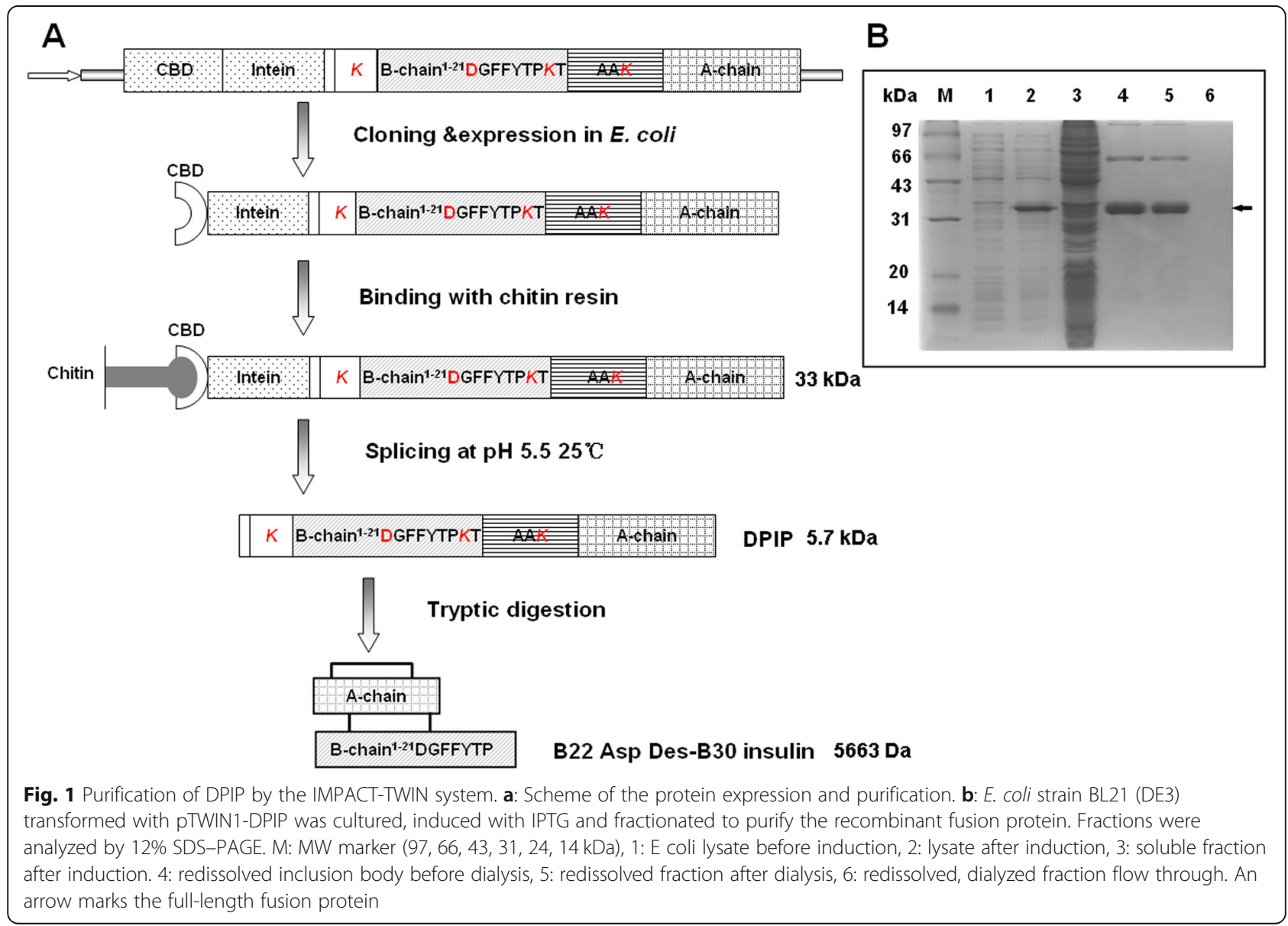


During optimization of the $\mathrm{pH}$-induced intein selfcleavage, we discovered that lowering the $\mathrm{pH}$ below physiological conditions aided the cleavage process. Fig. 2a shows proteins retained by the chitin column by SDS-PAGE after reaction at various temperature and $\mathrm{pH}$. Lane 1 shows that the fusion protein (CI-DPIP, 36 $\mathrm{kDa}$, marked by the top arrow) bound to the column before cleavage. Lanes 2 through 8 indicates that one of the products $(\mathrm{CBD}+$ intein $1,31 \mathrm{kDa}$, marked by the lower arrow), which also tightly associates with the column, decreases in intensities with the increase of $\mathrm{pH}$ (quantified in Fig. 2b). In general, we observed an increase in reaction activity (almost 100\%) at lower pHs compared to physiological $\mathrm{pH}$. This result is somewhat unexpected given the proposed mechanism for Cterminal intein cleavage involves deprotonation of the amino group [22].

This observation coincides with previous results $[19,23]$ in which the intein $\mathrm{C}$-terminal cleavage rate increased when the $\mathrm{pH}$ was lowered to 6.0. Therefore, we speculate that this phenomenon maybe general, and acidic conditions may benefit the self-cleavage reaction of other intein fusion proteins. Our data suggest that this particular Cterminal intein cleavage is perhaps catalyzed by a general acid (hydronium) via alternative mechanisms. However, at extremely acidic environments $(\mathrm{pH}<5.5)$, we suspect that DPIP ( $\mathrm{pI}=4.9$ ) may become unstable or insoluble. Therefore, we determine that the optimal cleavage $\mathrm{pH}$ for CIDPIP is 5.5. Previous studies suggest that intein may undergo different reaction mechanisms at varying $\mathrm{pHs}$. However, no previous study has investigated intein cleavage conditions below $\mathrm{pH} 6.0$ either experimentally or theoretically. Theoretical approaches proposed that at lower $\mathrm{pH}$ (6.0), especially below the $\mathrm{pKa}$ of histidine (6.04), the C-terminal cleavage reaction may take a different reaction path and increase its reaction rate [24]. Their result suggests that $\mathrm{N}$-protonation of the scissile peptide bond likely starts the C-terminal cleavage reaction, in contrast to a nucleophilic side chain cyclization mechanism proposed at physiological $\mathrm{pH}$ [22]. Our results support the acidcatalyzed reaction mechanism hypothesis at low pHs.

While having very little effect on cleavage efficiency at higher $\mathrm{pHs}$, temperature significantly increases the reaction rate at $\mathrm{pH} 6.5$ and lower. Among all three temperature conditions tested, $25^{\circ} \mathrm{C}$ shows, on average, $40 \%$ higher activity than $10^{\circ} \mathrm{C}$ and $30^{\circ} \mathrm{C}$ at $\mathrm{pH} 6.5-4.5$. Although higher temperatures usually produce higher reaction rates, CI-DPIP cleaved inefficiently at $30^{\circ} \mathrm{C}$, similar to $10^{\circ} \mathrm{C}$. This result suggests that the intein structure in this construct may be unstable and the active site perturbed at $30^{\circ} \mathrm{C}$.

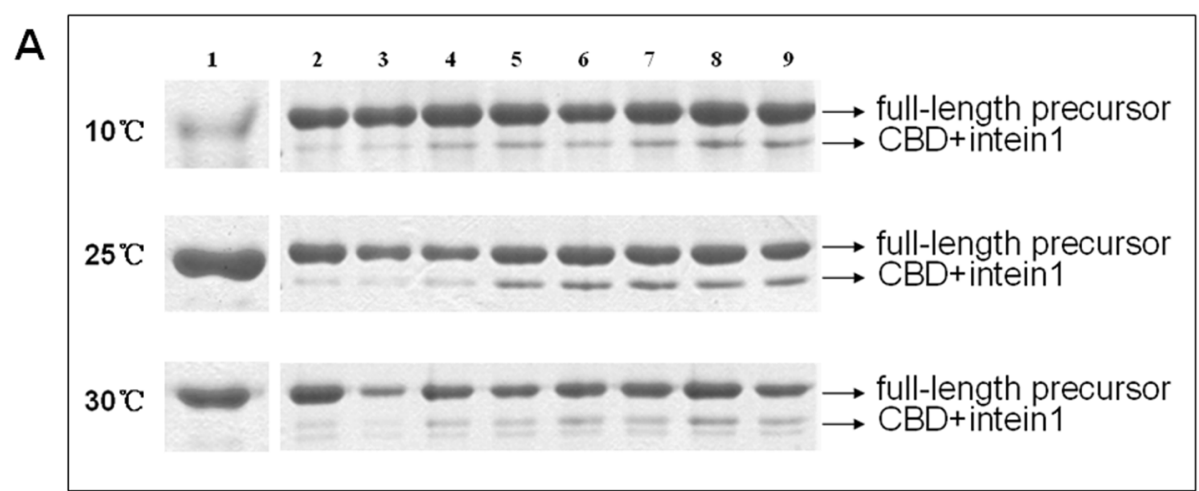

B

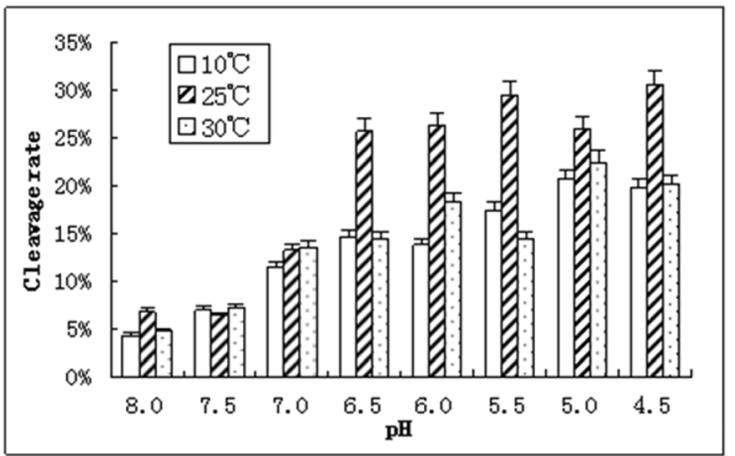

Fig. 2 Both temperature and pH affect Cl-DPIP cleavage in vitro. a: SDS-PAGE analysis of cleavage products after incubation at different pH and temperature. Lane 1: Input before cleavage reaction, Lanes 2-9: the resin after cleaving by TGE buffer with pH 8.0, 7.5, 7.0, 6.5, 6.0, 5.5, 5.0, 4.5. b: quantified cleavage ratio. All assays were carried out in triplicate and the average was used in this study; the error bars show standard deviations 
Our above data suggest that a simple $\mathrm{pH}$ change at $25^{\circ} \mathrm{C}$ can induce the release of tag-less DPIP from the recombinant protein. At $\mathrm{pH} 7.5-8.0$, the cleavage rate is the slowest (below 5\%), which means that the precursor can be stored safely under these conditions. Once shifted to $25^{\circ} \mathrm{C}$ and $\mathrm{pH} 5.5$, the intein self-cleavage reaction rate constant increased significantly to $30 \%$. Therefore, we conclude that the optimal temperature and $\mathrm{pH}$ for CIDPIP cleavage in this study is $25^{\circ} \mathrm{C}$ and $\mathrm{pH} 5.5$. By shifting the buffer $\mathrm{pH}$ from 8.0 to 5.5 , we can release pure insulin analog precursor DPIP from the column.

\section{Intein cleavage increases over two days}

After determining the optimal temperature and $\mathrm{pH}$ for the intein cleavage reaction, we set to improve the yield of DPIP by investigating different reaction durations. We had explored reaction time on the self-cleavage of intein by comparing the resin samples after 2, 4 and 6 days of cleavage. During a six-day incubation, resin samples were collected separately every other day. Subsequent SDS-PAGE (Fig. 3a) and band analysis (Fig. 3b) showed that the reaction rate increases drastically over the first
2 days and leveled off after that. Although small amounts of product continued to form over the next four days, the amount of additional product cannot justify the extra time required and the risk of degradation. Therefore, two days was chosen as the optimal reaction time.

\section{Urea inhibits intein self-cleavage}

Our study shows that the CI-DPIP construct is sensitive to urea. Since previous findings show that low concentrations of urea may increase the intein cleavage ratio [20], we decided to investigate the effect of urea on CIDPIP self-cleavage. We tested two urea cleavage conditions ( $1 \mathrm{M}$ and $2 \mathrm{M}$ ) against the no urea TGE buffer, and the results show that even one-molar urea can reduce reaction efficiency by $43 \%$ (Fig. 4). At two-molar urea concentration, the reaction efficiency dropped to below $10 \%$. This result suggests that our CI-DPIP fusion protein is more sensitive to folding, and slight perturbation abolishes the intein activity. This is also consistent with our temperature study that higher temperatures adversely affect the cleavage reaction, presumably due to misfolding at higher temperatures. It is possible that

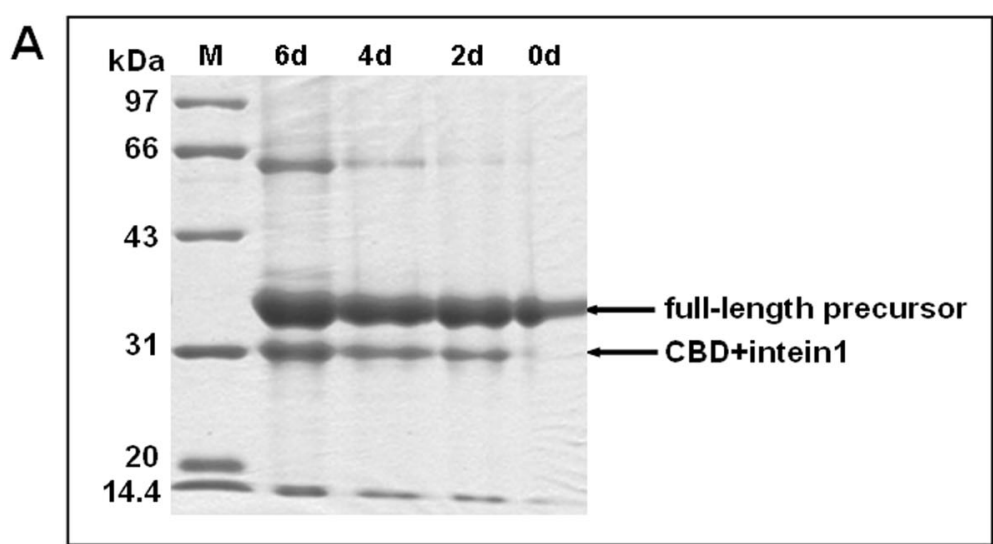

B

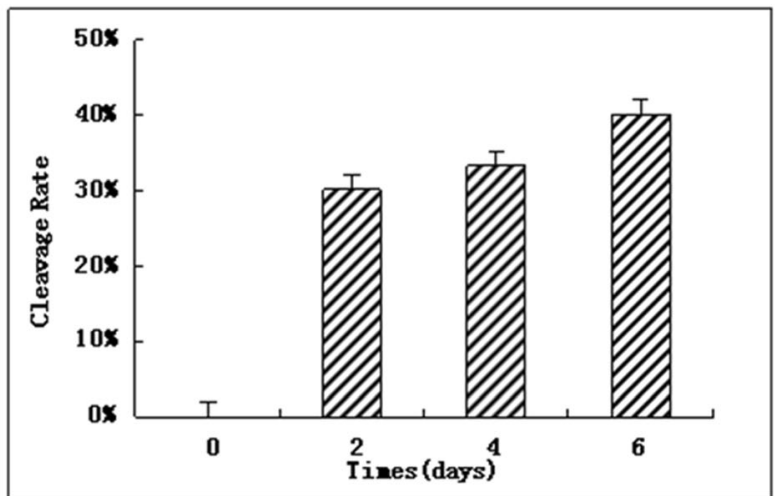

Fig. 3 Rate of CI-DPIP cleavage increases then slows down after two days. a: SDS-PAGE analysis of cleavage with different incubation time. Lanes 1-3 indicate resin after incubation of 6 days, 4 days and 2 days, respectively, and lane 4 indicates the input precursor without any cleavage (0d). Since the precursor is chemically stable in solution, so Lane 4 shows no CBD + intein fraction, M: molecular weight markers. b: Quantified cleavage ratio. All assays were carried out in triplicate and the average was used in this study; the error bars show standard deviations 


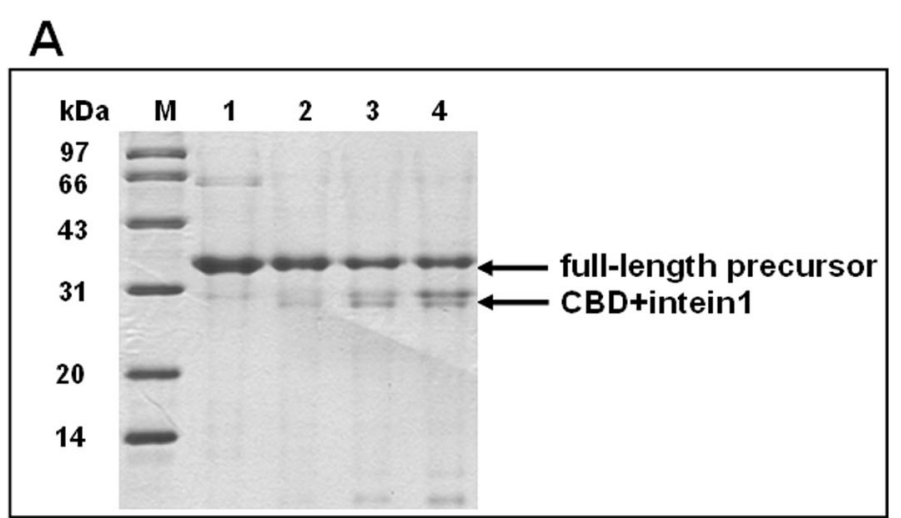

B

Fig. 4 Urea inhibits intein self-cleavage of CI-DPIP. a: SDS-PAGE analysis of cleavage in the buffer with different concentrations of urea. M: Molecular weight markers. Lane 1: input. Lanes 2 and 3: resin after cleavage by $2 \mathrm{M}$ and $1 \mathrm{M}$ urea-containing buffers. 4: resin after cleavage without urea. b: calculated cleavage ratio of every cleavage reaction. All the cleaving reaction was completed in the TGE buffer ( $\mathrm{pH} 5.5)$ at $25^{\circ} \mathrm{C}$ for 2 days

urea and higher temperate adversely affect CI-DPIP splicing by similar mechanisms.

\section{DPIP precursor generates pure B22D desB30 insulin analog}

Since the smaller size of DPIP $(\mathrm{MW}=5.7 \mathrm{kDa})$ does not allow accurate analysis on SDS-PAGE (Fig. 5a), 16.5\% tricine gels were required to visualize and analyze the fragment (Fig. 5b). Our result clearly identifies the pure DPIP eluted from the chitin matrix using conditions described above (Table 1).

To obtain the final folded insulin monomer, DPIP was subjected to trypsin digest. This step releases A-chain and B-chain from DPIP, removing the linker peptides (GRAK at the N-terminus and AAK between A-chain and B-chain) (Fig. 1a). Subsequently, two disulfide bonds spontaneously link A-chain and B-chain to form the final monomeric product. This insulin analog migrated as a single peak at 19.5 min during our HPLC purification (Fig. 6a), and subsequent mass-spectroscopy (Fig. 6b) confirmed a molecular mass of 5664 (theoretical $\mathrm{MW}=5663$ ). These data confirm that we have obtained pure (>90\%) and correctly folded B22D desB30 insulin analog through recombinant expression and purification. Table 2 summarizes total yield and purity of our DPIP purification.

We further determined the quality and monomeric state of the B22D desB30 insulin by comparing our sample with commercially available monomeric recombinant insulin through size exclusion chromatography (Fig. 7). The recombinant $\mathrm{B} 22 \mathrm{D}$ desB30 insulin eluted as a single peak at $15 \mathrm{~min}$, which coincides with the major peak in the commercial sample, confirming the purity and monomeric nature of the B22D desB30 analog. Moreover, our sample showed no detectable degradation or fragmentation (Fig. 7b). Since the target peptide remains

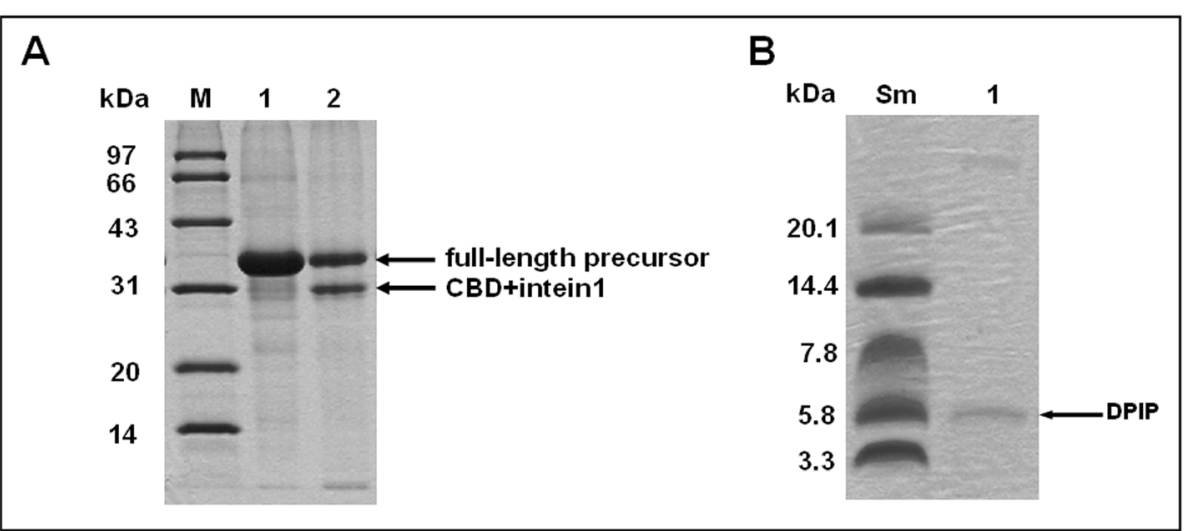

Fig. 5 DPIP is released from Cl-DPIP after intein cleavage. a: Cleavage of the DPIP fusion protein under the optimized condition. M: MW marker $(97,66,43,31,24,14 \mathrm{kDa})$. Lane 1: the chitin resin after protein binding. Lane 2: the resin after intein cleavage. The fractions were analyzed by 12\% SDS-PAGE. b: DPIP eluted from resin. M: MW marker (20.1, 14.4, 7.8, 5.8, 3.3 kDa). Lane 1: DPIP eluate. The fractions were analyzed by 16.5\% Tricine-SDS-PAGE 
Table 1 Summary of DPIP Purification

\begin{tabular}{llllc}
\hline $\mathrm{c}$ & $\begin{array}{l}\text { Total } \\
\text { Protien }^{\mathrm{a}}(\mathrm{mg})\end{array}$ & Target protein $^{\mathrm{b}}(\mathrm{mg})$ & Approximate purity $^{\mathrm{c}(\%)}$ & Yield $^{\mathrm{d}}(\%)$ \\
\hline Cell lysis & 200.33 & 133.82 (CBD-intein-DPIP) & 66.8 & 100 \\
Refolding of fusion protein & 156.26 & 116.73 (CBD-intein-DPIP) & 74.7 & 87.2 \\
Chitin column and intein-mediated cleavage & 0.621 & 0.548 (DPIP) & 88.3 & 2.4 \\
\hline
\end{tabular}

One liter of culture contained about $3.2 \mathrm{~g}$ wet weight cells

a: Total protein was quantified by Bradford assay

b: The amount of fusion protein was calculated based on the following formula: target protein = total protein amount $x$ approximate purity

c: The purities of fusion protein were determined by densitometry analysis of their corresponding SDS gel bands

$d$ : The relative low recovery of DPIP was partially due to the low molecular weight of DPIP (6 kDa) compared to the fusion precursor CBD-intein-DPIP ( 33 kDa)

stable, we recommend using large-scale SEC to separate it for mass production.

Since misformed disulfides will induce lower solubility [25-27], faster degradation [28, 29], and unwanted aggregation or precipitation [30, 31], our final product displayed excellent solubility and superior stability, compared to commercially available insulin (Fig. 7), indicating no evidence of any misformed disulfides. This result also agrees with previous studies [32, 33] where similar recombinantly expressed proinsulin all folded correctly.

\section{Conclusion}

This study aims to explore a cheaper alternative for producing monomeric human insulin analog to treat diabetes. Compared to the chemical synthesis and yeast preparation, our recombinant monomeric B22Asp desB30 insulin analog is fused to an N-terminal chitinbinding domain and intein self-cleavage tag. The fusion protein binds to chitin resins and is subsequently washed off. Next, trypsin digest releases mature insulin. The resulting product appears monomeric, $>90 \%$ pure and devoid of any exogenous enzyme. Thus, biologically active insulin analog can be efficiently produced in bacteria and potentially applicable in the treatment of human diabetes.

\section{Methods}

All the buffers used in this study are summarized in Table 2.

\section{Plasmid construction}

The coding sequence of the insulin precursor (PIP) was used as a template for subsequent site-directedmutagenesis amplification (B22D) with Pfu under standard conditions using the primer pair M1/M2 (sequence: $5^{\prime}$ TTGGTCTGTGGTGAAGACGGTTTCTTCTACACC-3' and 5'-GGTGTAGAAGAAACCGTCTTCACCACAGACCAA-3'). The coding sequence of B22D desB30 was flanked by $5^{\prime} \mathrm{NcoI}$ and $3^{\prime}$ PstI restriction sites for inserting into the pTWIN1 (New England Biolabs) expression vector with the primer pair P1/P2 (sequence: 5'-ATATCCATGG GC AAGTTCGTCAACCAACA-3' and 5'-ATATCC ATGGGCAAGTTCGTCAA CCAACA-3'). P2 inserted an additional lysine residue at the N-terminus of DPIP to

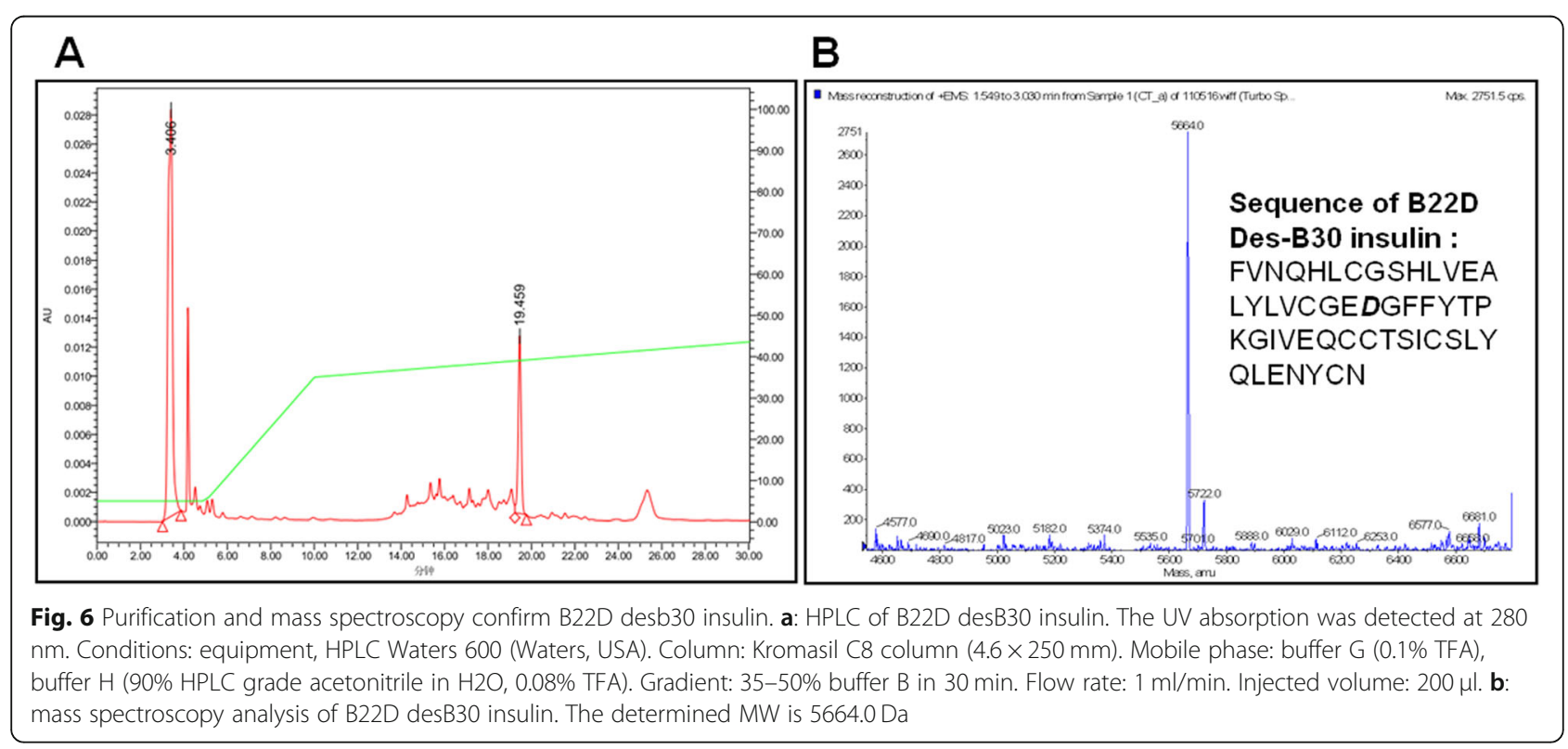


Table 2 Buffers used in protein purification

\begin{tabular}{|c|c|}
\hline Buffers & Details \\
\hline Buffer A & $50 \mathrm{mM}$ Tris-HCl, $2 \mathrm{mM}$ EDTA, $100 \mathrm{mM} \mathrm{NaCl}$ \\
\hline Buffer B & 50 mM Tris-HCl, 1 mM EDTA, 100 mM NaCl,1\% Tween \\
\hline Buffer C & $\begin{array}{l}50 \mathrm{mM} \text { Tris-HCl, } 1 \text { mM EDTA, } 100 \text { mM NaCl, 1\% } \\
\text { Tween, } 4 \text { M Urea }\end{array}$ \\
\hline Buffer D & 50 mM Tris- $\mathrm{HCl}, 1$ mM EDTA, 100 mM NaCl, 3\% Tween \\
\hline Buffer $\mathrm{E}$ & $\begin{array}{l}50 \mathrm{mM} \text { Tris-HCl, } 1 \text { mM EDTA, } 100 \text { mM NaCl,0.5\% } \\
\text { Tween }\end{array}$ \\
\hline Buffer $F$ & $\begin{array}{l}50 \mathrm{mM} \text { Tris- } \mathrm{HCl}, 1 \mathrm{mM} \text { EDTA, } 10 \mathrm{mM} \beta \text { - } \\
\text { Mercaptoethanol, } 2 \text { mM Sodium deoxycholate pH 8.0, } \\
8 \\
\text { M Urea }\end{array}$ \\
\hline TGE buffer & $\begin{array}{l}50 \mathrm{mM} \text { Tris-HCl, } 0.5 \mathrm{mM} \text { EDTA,50 mM NaCl, 5\% } \\
\text { Glycerol, 1\% Glycine, 0.1\% Glutathione pH } 8.0\end{array}$ \\
\hline $\begin{array}{l}\text { Digestion } \\
\text { buffer }\end{array}$ & $\begin{array}{l}20 \mathrm{mM} \text { Tris- } \mathrm{HCl}, 200 \mathrm{mM} \mathrm{NaCl} \text { and } 1 \mathrm{mM} \text { EDTA, } \\
\mathrm{pH} 8.0\end{array}$ \\
\hline Buffer $\mathrm{G}$ & $0.1 \%$ TFA \\
\hline Buffer $\mathrm{H}$ & 90\% HPLC grade acetonitrile in $\mathrm{H}_{2} \mathrm{O}, 0.08 \%$ TFA \\
\hline
\end{tabular}

introduce a trypsin cleavage site. The recombinant plasmid was subsequently transformed into $E$. coli $\mathrm{DH} 5 \alpha$ cells and confirmed by colony PCR and sequencing (Invitrogen Biotechnology Co., Ltd.). Sequences of the primers for colony PCR were primer $\mathrm{F}$ and $\mathrm{R}$ (5'-ACTGGGACTCCATC GTTTCT-3' and 5'-ATATCTGCAGCTAGTTACAGTA GTTCT-3'). The sequence-confirmed recombinant plasmid was named pTWIN1-DPIP. The design of the recombinant protein and purification scheme are illustrated in Fig. 1.

\section{Protein expression}

All expression experiments were performed in duplicate with good reproducibility. First, pTWIN1-DPIP were transformed into E. coli strain BL21 (DE3) and grown to optical density (A600) of 0.5 , in $300 \mathrm{ml}$ of LB media (2\% tryptone, $1 \%$ yeast extract, $2 \% \mathrm{NaCl}, \mathrm{w} / \mathrm{v}$ ) containing $100 \mu \mathrm{g} / \mathrm{ml}$ ampicillin at $37^{\circ} \mathrm{C}$. Next, isopropyl 1-thio- $\beta$ $\mathrm{D}$-galactopyranoside (IPTG) was added to the final concentration of $0.1 \mathrm{mM}$ to induce expression for $4 \mathrm{~h}$ at $37^{\circ} \mathrm{C}$. The cells were harvested by centrifugation at $3000 \mathrm{~g}$ for $15 \mathrm{~min}$ at $4{ }^{\circ} \mathrm{C}$ and stored at $-80^{\circ} \mathrm{C}$.

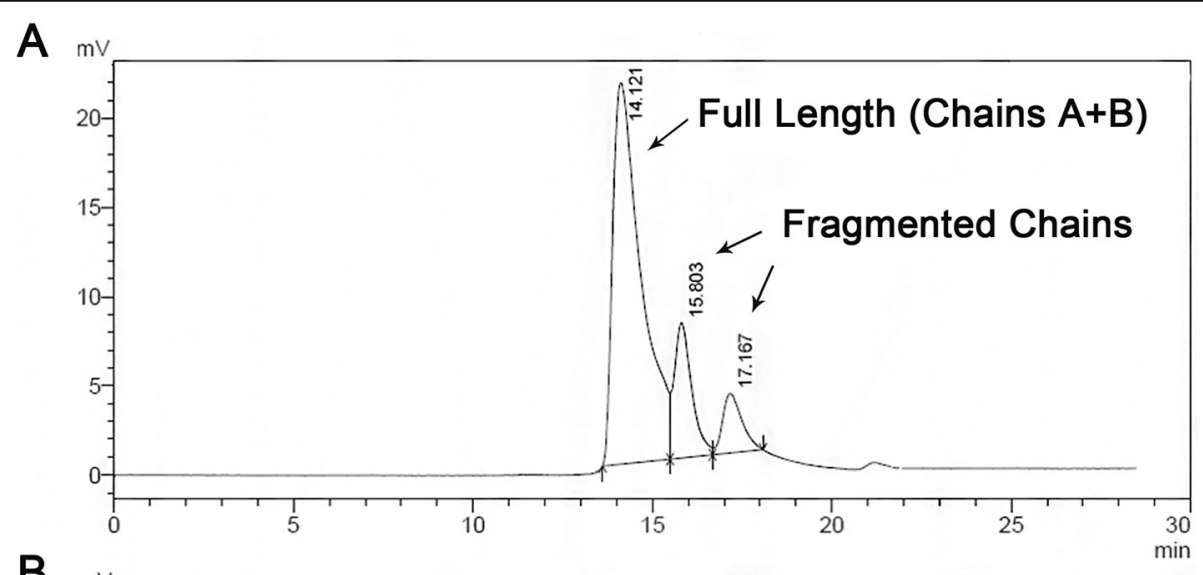

B

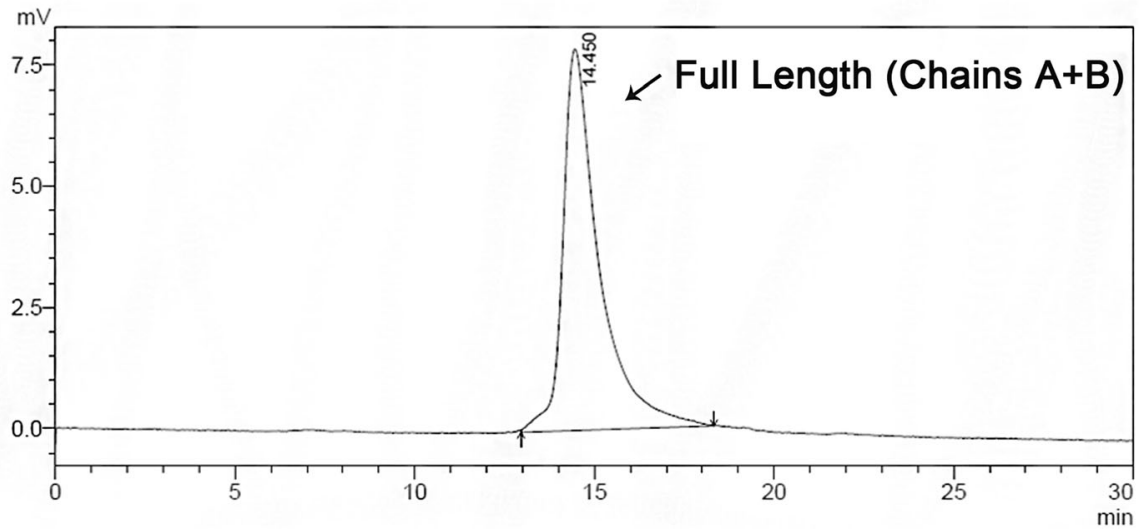

Fig. 7 SEC elution profile of B22D desb30 insulin compared with commercial sample. Size exclusion chromatography of a): commercially available insulin sample and b). B22D desB30 insulin. The UV absorption was detected at $280 \mathrm{~nm}$. Column: GE Superdex 75 Flow rate: $0.5 \mathrm{ml} / \mathrm{min}$. FPLC: GE Healthcare Purifier 100 


\section{Protein purification}

All subsequent steps in this section were performed on ice or at $4{ }^{\circ} \mathrm{C}$ unless otherwise mentioned. Cell pellets were resuspended in ice-cold PBS (pH 8.0) at a ratio of 1:10 (w/ v) and lysed by sonication. Since the DPIP is enriched in the insoluble fraction, the cell extracts were centrifuged at $10,000 \mathrm{~g}$ for $30 \mathrm{~min}$ at $4{ }^{\circ} \mathrm{C}$ to remove the soluble fraction. The pellets were washed sequentially with buffer A-E before redissolved thoroughly in ice-cold buffer F. Next, the mixture was dialyzed against TGE buffer ( $\mathrm{pH}_{-}$8.0) with different concentrations of urea $(6 \mathrm{M}, 4 \mathrm{M}, 2 \mathrm{M}, 1 \mathrm{M}$, and $0 \mathrm{M})$. The insoluble fraction was removed by centrifugation at $10,000 \mathrm{~g}$ for $30 \mathrm{~min}$.

Then the supernatant was applied to pre-equilibrated chitin affinity resins (resin diameter $=50-70 \mu \mathrm{m}$, New England Biolabs). The on-column cleavage of the intein fusion protein was conducted in 2 bed volumes of TGE buffer with a pH gradient (8.0, 7.5, 7.0, 6.5, 6.0, 5.5, 5.0, and 4.5) at desired temperatures $\left(10^{\circ} \mathrm{C}, 25^{\circ} \mathrm{C}, 30^{\circ} \mathrm{C}\right)$. The flow through was collected and analyzed by $12 \%$ SDS-PAGE and 16.5\% Tricine -SDS-PAGE.

\section{Quantifying the intein splice efficiency}

Premature cleavage was estimated by quantifying the scanned SDS polyacrylamide gels with Bandscan 5.0 (Glyko). Bands corresponding to full-length fusion protein (CBD-intein1-DPIP, CI-DPIP) and CBD-intein1 tag (CI) were quantified by scanning densitometry and normalized against their molecular weights.

\section{Optimizing tryptic digestion}

The eluate from intein splicing was digested by trypsin at $30^{\circ} \mathrm{C}$ for one hour to obtain the final B22D desB30 insulin analog. We used an enzyme/substrate ratio of 1 : $200(\mathrm{w} / \mathrm{w})$. The mixture was subsequently purified by high-pressure liquid chromatography (Wasters) (C8 column, acetonitrile and trifluoroacetic acid (TFA) as mobile phases). Monomeric B22D insulin analog was eluted at 19.5-min mark with a flow rate of $1 \mathrm{ml} / \mathrm{min}$ and a buffer $\mathrm{H}$ gradient of $35-50 \%$ over $30 \mathrm{~min}$.

To access the quality of our sample, both the commercial insulin (Insulin Injection, MW 5778) and the B22D desB30 insulin analog was subjected to size exclusion chromatography (SEC) using Superdex 75 (GE healthcare) column under standard conditions.

\section{Abbreviations \\ B22D: B22Asp desB30 insulin; B22D-PIP/ DPIP: Insulin precursor of B22D; CBD: Chitin binding domain; Cl: Chitin binding domain- intein 1 tag; IPTG: Isopropyl 1-thio- $\beta$-D-galactopyranoside; SEC: Size exclusion chromatography; TFA: Trifluoroacetic acid}

\section{Acknowledgements}

We thank Prof. Xiaoxia Shao from Tongji University (Shanghai, China) for determining the molecular weight by mass spectroscopy, and Dr. Lu Wang from Donghua University for proofreading the manuscript.

\section{Authors' contributions}

T. C. designed and conceived the study. B. W. and Y. P. conducted experiments and data analysis. T. C., M. Z. and C. L. drafted the manuscript. Y. Z., C. L., A.A.S. and G. W. S. critically revised the manuscript. C. L. was the senior author providing intellectual input and supervision as well as the funding for the project. All authors read and approved the final manuscript.

\section{Funding}

The design of the study, collection, analysis, interpretation of data, and in writing the manuscript was shared equally by the following funding: Shanghai Science and Technology Committee (19ZR1471100, 19410741800), Fundamental Research Funds for the Central Universities (19D210501, 19D310517), the National College Student Innovation Experiment Program (105-03-0178028, 105-03-0178029, 105-03-0178229, 105-03-0178139).

\section{Availability of data and materials}

The datasets supporting the conclusions of this study are available upon request from the corresponding author.

\section{Ethics approval and consent to participate}

This article does not contain any studies with human participants or animals performed by any of the authors.

\section{Consent for publication}

The authors provide consent for publication.

\section{Competing interests}

The authors declare no Conflicts of Interest.

\section{Author details}

${ }^{1}$ Key Laboratory of Science and Technology of Eco-Textiles, Ministry of Education, College of Chemistry, Chemical Engineering and Biotechnology, Donghua University, 2999 North Ren Min Rd, Shanghai 201620, China. ${ }^{2}$ Department of Orthopaedic Surgery, Musculoskeletal Oncology Division, University of Michigan Medical School, Ann Arbor, MI 10, USA.

Received: 1 June 2019 Accepted: 3 January 2020

Published online: 09 January 2020

\section{References}

1. Zimmet P, Al E. Global and societal implications of the diabetes epidemic Nat. 2001:414:782-7.

2. Forbes JM, Cooper ME. Mechanisms of diabetic complications. Physiol Rev 2013 Jan:93(1):137-88

3. International Diabetes Federation. IDF Diabetes Atlas, 9th edn. Brussels, Belgium: 2019. Available at: http://www.diabetesatlas.org. Accessed 9 Oct 2019

4. Moses SG, Kapur A. Animal insulins. J Assoc Phys India. 1997:(Suppl 1):41-4.

5. Mane K, Chaluvaraju KC, Niranjan MS, et al. Review of insulin and its analogues in diabetes mellitus. J Basic Clin Pharm. 2012;3:283.

6. Horuk R, Blundell TL, Lazarus NR, Neville RW, Stone D, Wollmer A. A monomeric insulin from the porcupine (Hystrix cristata), an Old World hystricomorph. Nat. 1980;286:822-4 [PubMed].

7. Zhu SQ, Li TF, Cui DF, Cao QP, Zhang YS. Effect of B22-arginine replacement on the biological activity of insulin. Sci Sinica. 1981;24:264-71 [PubMed].

8. Rose K, Rees AR, Drake CS, et al. The role of the arginine-B22 residue in insulin action. Biochem J. 1981;195:765.

9. Hai-Juan DU, Jia-Hao SHI, Da-Fu CUI, You-Shang ZHANG. B22 Glu des-B30 insulin: a novel monomeric insulin. Acta Biochim Biophys Sin. 2006:38:53742.

10. Liu H, Zhou X, Xie F, et al. An efficient trypsin digestion strategy for improving desB30 productivity from recombinant human insulin precursor fusion protein. Process Biochem. 2013, 48, 965-971. [CrossRef] [PubMed].

11. Paulus $H$. Protein splicing and related forms of protein antoprocessing. Annu. Rev. Biochem. 2000, 69, 447-496. [CrossRef] [PubMed].

12. Perler FB, Davis EO, Dean GE, Gimble FS, Jack WE, Neff N, et al. Protein splicing elements: inteins and exteins-a definition of terms and recommended nomenclature. Nucleic Acids Res. 1994:22:1125-7 [PubMed].

13. Mills K V , Johnson M A, Perler F B. Protein splicing: how inteins escape from precursor proteins. J Biol Chem. 2014, 289, 14498-14505. [CrossRef] [PubMed]. 
14. Vila-Perello M, Muir TW. Biological applications of protein splicing. Cell. 2010 143:191-200 [PubMed]

15. Volkmann G, Murphy PW, Rowland, EE, Cronan JE Jr, Liu XQ, Blouin C, et al. Intein-mediated cyclization of bacterial acyl carrier protein stabilizes its folded conformation but does not abolish function. J Biol Chem. 2010, 285, 8605-8614. [CrossRef] [PubMed].

16. Chen T, Li L, Hao H, Qiao Y. Preparation of monomeric B27 Lys destripeptide insulin by intein mediated expression in Escherichia coli. Protein Expr Purif. 2011, 80, 152-156. [CrossRef] [PubMed].

17. Pirzer T, Becher KS, Rieker M, et al. Generation of potent anti-HER1/2 immunotoxins by protein ligation using split inteins. ACS Chem Biol. 2018 [CrossRef] [PubMed].

18. Collins ED, Espinoza A, Le LT, Kato M. Cloning the human vitamin D receptor into the pTWIN-1 expression vector. J Steroid Biochem Mol Biol. 2010, 121, 121-123. [CrossRef] [PubMed].

19. Coolbaugh M J, Tang M J S, Wood D W. High-throughput purification of recombinant proteins using self-cleaving intein tags. Anal Biochem. 2017, 516, 65-74. [CrossRef] [PubMed].

20. Goeddel DV, Kleid DG, Bolivar F, Heyneker HL, Yansura DG, Crea R, et al. Expression in Escherichia coli of chemically synthesized genes for human insulin. Proc Natl Acad Sci U S A. 1979, 76, 106-110. [CrossRef] [PubMed]

21. Berg H, Walter M, Mauch L, Seissler J, Northemann W. Recombinant human preproinsulin. Expression, purification and reaction with insulin autoantibodies in sera from patients with insulin-dependent diabetes mellitus. J Immunol Methods. 1993;164:221-31 [PubMed].

22. Eryilmaz E, Shah N, Muir T, et al. Structural and dynamical features of inteins and implications on protein splicing. J Biol Chem. 2014, 289, 14506-14511. [CrossRef] [PubMed].

23. Wood DW, Wu W, Belfort G, Derbyshire V, Belfort M. A genetic system yields self-cleaving inteins for bioseparations. Nat Biotechnol. 1999, 17, 889-892. [CrossRef] [PubMed].

24. Shemella P, Pereira B, Zhang Y, Van Roey P, Belfort G, Garde S, et al. Mechanism for Intein C-Terminal Cleavage: A Proposal from Quantum Mechanical Calculations. Biophys J. 2007,92, 847-853. [CrossRef] [PubMed].

25. Kim BK, Kang H, Doh KO, Lee SH, Park JW, Lee SJ, et al. Homodimeric SV4O NLS peptide formed by disulfide bond as enhancer for gene delivery. Bioorg Med Chem Lett. 2012 Sep 1;22(17):5415-8.

26. Sallada ND, Dunn K, Berger BW. A structural and functional role for disulfide bonds in a class II Hydrophobin. Biochemistry. 2018 Feb 6;57(5): $645-53$

27. Singh S, Akhter MS, Dodt J, Sharma A, Kaniyappan S, Yadegari H, et al. Disruption of structural disulfides of coagulation FXIII-B subunit. Functional Implications for a Rare Bleeding Disorder Int J Mol Sci. 2019 Apr;22:20(8).

28. Liu CH, Huang CY, Huang CC. Occupational neurotoxic diseases in taiwan Saf Health Work. 2012 Dec;3(4):257-67.

29. Weil-Ktorza O, Rege N, Lansky S, Shalev DE, Shoham G, Weiss MA, et al. Substitution of an internal disulfide bridge with a Diselenide enhances both Foldability and stability of human insulin. Chemistry. 2019 Jun 26;25(36): 8513-21.

30. Serebryany E, Yu S, Trauger SA, Budnik B, Shakhnovich El. Dynamic disulfide exchange in a crystallin protein in the human eye lens promotes cataractassociated aggregation. J Biol Chem. 2018 Nov 16;293(46):17997-8009.

31. Hawk LML, Pittman JM, Moore PC, Srivastava AK, Zerweck J, Williams JTB, et al. $\beta$-Amyloid model core peptides: effects of hydrophobes and disulfides. Protein Sci 2019 Nov 11.

32. Zhang $\mathrm{H}$, Chen $\mathrm{Y}$, Feng YM. A recombinant monomeric human insulin mutant with resistance to trypsin design, preparation and characterization. Acta Biochim Biophys Sin. 2000;32(6):635-6.

33. Mikiewicz D, Bierczyńska-Krzysik A, Sobolewska A, Stadnik D, Bogiel M, Pawłowska M, Wójtowicz-Krawiec A, et al. Soluble insulin analogs combining rapid- and long-acting hypoglycemic properties - From an efficient $E$. coli expression system to a pharmaceutical formulation. PLoS One. 2017 Mar 15;12(3):e0172600.

\section{Publisher's Note}

Springer Nature remains neutral with regard to jurisdictional claims in published maps and institutional affiliations.

\section{Ready to submit your research? Choose BMC and benefit from:}

- fast, convenient online submission

- thorough peer review by experienced researchers in your field

- rapid publication on acceptance

- support for research data, including large and complex data types

- gold Open Access which fosters wider collaboration and increased citations

- maximum visibility for your research: over $100 \mathrm{M}$ website views per year

At BMC, research is always in progress.

Learn more biomedcentral.com/submissions 